\title{
Kan vi stole på urinstiks?
}

Urinstiks er mye brukt i klinikken for å diagnostisere

urinveisinfeksjon hos eldre til tross for at den ikke skiller mellom en urinveisinfeksjon og asymptomatisk bakteriuri.

\section{Forfattere}

\section{Stine Veronica Eriksen}

Avansert geriatrisk sykepleier

Sykehuset Østfold

Pia Cecilie Bing-Jonsson

Førsteamanuensis

Høgskolen i Buskerud og Vestfold

\section{Nøkkelord}

Urinstiks Urinveisinfeksjon Eldre Sykehjem Hjemmetjeneste

Sykepleien Forskning 2016 10(1)

DOI: 10.4220/Sykepleienf.2016.58641

\section{SAMMENDRAG}

Bakgrunn: Urinveisinfeksjon er den vanligste bakterielle infeksjonstypen hos den eldre befolkningen. Det er mange tilfeller av overbehandling blant denne populasjonen, blant annet på grunn av at differensialdiagnostikken mellom urinveisinfeksjon og asymptomatisk bakteriuri er vanskelig. Urinstiks er et hjelpemiddel som er mye brukt i klinikken for å diagnostisere urinveisinfeksjon hos eldre.

Hensikt: Å unders $\emptyset$ ke hvorvidt urinstiks er et pålitelig hjelpemiddel for å diagnostisere urinveisinfeksjon hos eldre pasienter i sykehjem og hjemmetjenester.

Metode: Systematisk litteraturgjennomgang av kvantitative primærstudier. Vi gjennomførte systematiske søk i databasene Cinahl, PubMed, Cochrane og Embase i januar 2015. 
Resultat: Fem av de seks inkluderte studiene viste at verken leukocytter eller nitritt eller en kombinasjon av de to var pålitelige for sensitivitet eller spesifisitet for klinisk bruk. En positiv urinstiks har stor sjanse for å være falsk positiv. Gjennomsnittet av den positive prediktive verdien fra studiene viser 61 prosent. En negativ urinstiks, derimot, ser ut til å være mer pålitelig, der den negative prediktive verdien viser i gjennomsnitt 83 prosent.

Konklusjon: Litteraturgjennomgangen viser at urinstiks ikke ser ut til å være et hensiktsmessig hjelpemiddel i diagnostiseringen av urinveisinfeksjon hos eldre, fordi den er lite pålitelig og ikke kan skille mellom en urinveisinfeksjon og asymptomatisk bakteriuri. Til tross for dette har vi tilsynelatende ikke noe annet hjelpemiddel som er bedre. Sykepleierne har vist seg å ha en viktig rolle i urinprøvetaking og oppstart av antibiotikabehandling ved urinveisinfeksjon hos eldre. Derfor er det viktig at de kjenner til begrensningene til urinstiks, indikasjoner for bruk av urinstiks, og hvordan man skal tolke en urinstiks.

Urinstiks er et svært vanlig hjelpemiddel brukt til å diagnostisere urinveisinfeksjon (UVI) blant eldre pasienter på sykehjem og i hjemmetjenester, men er den pålitelig? I denne litteraturstudien forsøker vi å svare på dette spørsmålet og diskutere eventuelle alternative løsninger.

UVI er den vanligste infeksjonen i den eldre delen av befolkningen, og forekomsten er størst blant pasienter på sykehjem (1). UVI er en samlebetegnelse på infeksjon i urinveiene, og pasienten smittes vanligvis av sin egen tarmflora. Tilstanden fører i mange tilfeller til plagsomme symptomer og i verste fall sepsis og død (2). For å starte behandling for en UVI blant voksne kvinner og menn holder det vanligvis med en sykehistorie. Det viktigste hjelpemiddelet for å diagnostisere UVI er å undersøke urinprøven, men selv den kan sløyfes om symptomene er klare, og vedkommende kjenner dem igjen fra før (3).

\section{Vanskelig å stille diagnose}


Metoden for urinprøvetaking må være kunnskapsbasert

og krever spesielle hensyn hos pasienter som bruker inkontinensprodukter eller urinkateter $(4,5)$. Hos eldre kan diagnosen UVI være vanskelig å stille da de vanlige symptomene ikke alltid er til stede. Det som vanskeliggjør diagnostikken ytterligere, er den høye andelen pasienter som har asymptomatisk bakteriuri (ASB) (2). Forekomsten av ASB på sykehjem er estimert til 25-50 prosent for kvinner og 15-40 prosent for menn (6). Forskjellen på UVI og ASB er fremstilt i tabell 1 (2, 7-10). I motsetning til UVI skal ASB ikke behandles med antibiotika. Bivirkninger forårsaket av medisiner er hyppigere blant eldre personer enn blant yngre (11), og adekvat antibiotikabruk er derfor viktig for å unngå unødvendige bivirkninger, unngå utvikling av antibiotikaresistens og redusere kostnader (12).

Tabell 1: Forskjellen mellom urinveisinfeksjon (UVI) og asymptomatisk bakteriuri (ASB) hos den eldre befolkningen

\begin{tabular}{|c|c|c|}
\hline & Urinveisinfeksjon (UVI) & Asymptomatisk bakteriuri (ASB) \\
\hline Definisjon & $\begin{array}{l}\text { Signifikant bakteriuri når } \\
>10^{5} \text { bakterier/ml urin og } \\
\text { symptomer på urinveisin- } \\
\text { feksjon }\end{array}$ & $\begin{array}{l}\text { Signifikant oppvekst ( }>10^{5} \text { bak- } \\
\text { terier/ml urin) av samme bak- } \\
\text { terieart i to etterfølgende prøver } \\
\text { og manglende symptomer på } \\
\text { urinveisinfeksjon }\end{array}$ \\
\hline Symptomer & $\begin{array}{l}\text { Smerter og svie ved vann- } \\
\text { lating. } \\
\text { Hyppig vannlating } \\
\text { Nyoppstått } ø \text { kt vannlating- } \\
\text { strang og eventuell lekkasje } \\
\text { Suprapubiske smerter } \\
\text { Atypiske symptomer hos } \\
\text { skrøpelige og kognitivt svek- } \\
\text { kete pasienter, som } \\
\text { nyoppstått delirium, fall- } \\
\text { tendens, uro, aggressivitet, } \\
\text { nedsatt matlyst, ADL-svikt } \\
\text { Temperatur over } 37,9 \text { grader } \\
\text { eller } 1,5 \text { grader over nor- } \\
\text { malen oftest til stede ved } \\
\varnothing v r e \text { UVI }\end{array}$ & $\begin{array}{l}\text { Manglende symptomer på urin- } \\
\text { veisinfeksjon }\end{array}$ \\
\hline Behandling & $\begin{array}{l}\text { Behandles med antibiotika - } \\
\text { i første omgang smalspektret } \\
\text { antibiotika }\end{array}$ & $\begin{array}{l}\text { Skal ikke behandles fordi det } \\
\varnothing \text { ker resistensutvikling. Pasienter } \\
\text { med ASB har ikke } \varnothing \text { kt risiko for } \\
\text { sykelighet eller mortalitet, og } \\
\text { bakteriuri har likevel en tendens } \\
\text { til å komme tilbake etter behan- } \\
\text { dling }\end{array}$ \\
\hline
\end{tabular}


I eldreomsorgen i dag brukes urinstiks ofte ved mistanke om UVI (2). Urinstiks er en papirstrimmel tilsatt kjemiske stoffer som dyppes i urinen. Hvis det for eksempel er bakterier, blod eller sukker i urinen, vil strimmelen skifte farge (13). Figur 1 beskriver kort hva de ulike reagensene på en urinstiks betyr $(4,14-16)$. Urinstiks blir brukt når det er mistanke om UVI på bakgrunn av de typiske symptomene på UVI. Urinstiks brukes også ved endring i tilstanden til den eldre, som kan være alt fra gråt til økt uro (17).

Urinstiks er utarbeidet for å diagnostisere blant annet UVI. Den er lett å bruke, den er billig, og den er et hjelpemiddel som gir raskt resultat. Urinstiks har vært på markedet i 25 år, og mange studier har evaluert dens nøyaktighet for å oppdage UVI og bakteriuri i forskjellige populasjoner og aldersgrupper (18). En urinstiks kan fortelle oss om det er leukocytter eller nitritt i urinen, men den kan ikke skille mellom en UVI og en ASB. Når man vet at ASB er svært utbredt blant eldre, er det trolig stor overbehandling om man kun diagnostiserer ut fra en urinstiks.

\section{Er urinstiks pålitelig?}

Litteraturen understøtter at det er et kjent problem med overbehandling av UVI (19). En studie viste at når leger kun brukte teststrimmelen for å diagnostisere klassiske nedre urinveissymptomer, fikk 47 prosent av pasientene antibiotika upassende, mens 11 prosent ikke fikk den behandlingen de skulle hatt (20). De fleste studiene som omhandler urinstiks, er imidlertid gjort på andre befolkningsgrupper enn eldre. Når vi vet at det er høy forekomst av både UVI og ASB blant den eldre befolkningen, og at det er viktig å skille mellom disse, er det interessant å undersøke hvor pålitelig urinstiks er for eldre pasienter. Forskningsspørsmålet i denne studien var derfor følgende:

Er urinstiks et pålitelig hjelpemiddel for å diagnostisere UVI hos eldre pasienter i sykehjem og hjemmetjenester? 


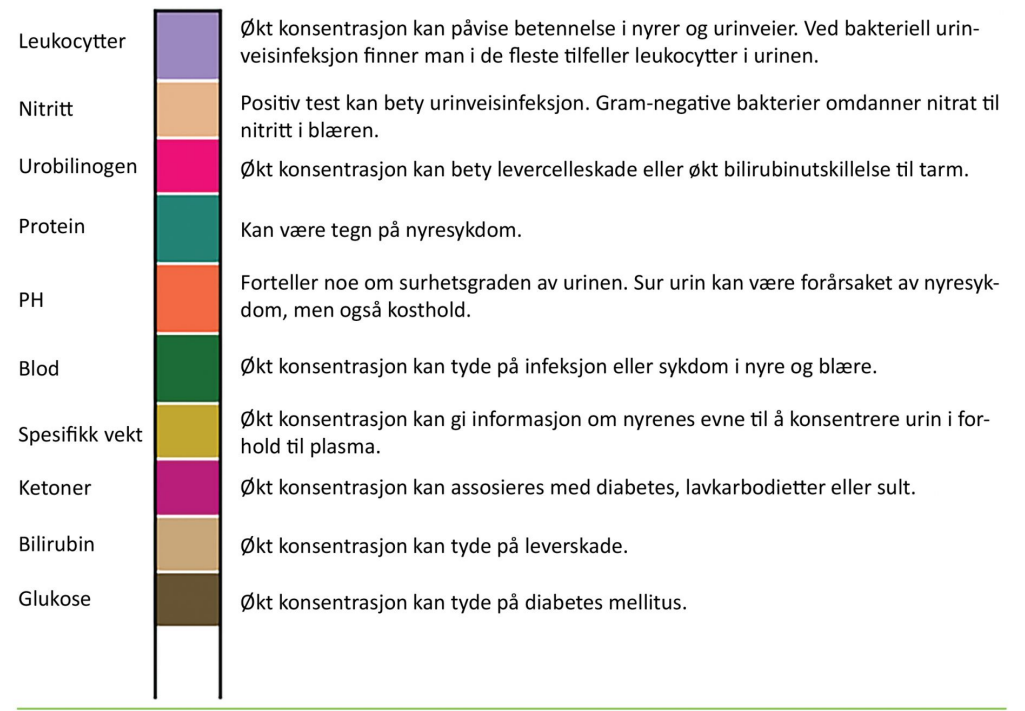

Figuren beskriver kort hva de ulike reagensene betyr.

\section{Metode}

Denne litteraturstudien er basert på kvantitative primærstudier som vurderer urinstiks som hjelpemiddel i diagnostiseringen av urinveisinfeksjon hos eldre pasienter i sykehjem eller hjemmetjenester. Inklusjonskriteriene som ble valgt for studien, var at artiklene måtte være primærstudier. Utvalget måtte være pasienter over 65 år, artiklene måtte være på engelsk eller et skandinavisk språk, og studiene måtte omhandle påliteligheten av urinstiks som hjelpemiddel i diagnostiseringen av UVI. Vi foretok ikke noen avgrensning i artiklenes årstall for publisering fordi det var viktig å finne all forskning på dette temaet. Vi gjennomførte systematiske søk i databasene PubMed, Cinahl, Embase og Cochrane i januar 2015. Vi brukte følgende nøkkelord: «urinary tract infection*, UTI, reagent strip, urine dipstick, dipstick urinalysis, Urine* adj stick* TW», som ble kombinert med «residential facilities, nursing homes, long term care, homes of the aged, primary care».

\section{三 «UUrinveisinfeksjon er den vanligste infeksjonen i den eldre delen av befolkningen.»"»}


Søkene ble noe ulike i de forskjellige databasene grunnet databasenes ulike oppbygning. Til slutt ble det lagt til et filter, slik at artiklene kun omhandlet personer over 65 år. Vi fant totalt 100 artikler i de ulike databasene, og ved gjennomgang ble 20 duplikater luket ut. De 80 gjenstående artiklene ble screenet ved å lese overskrifter og abstrakter. Vi ekskluderte i alt 65 artikler fordi de ikke var forskningsartikler, ikke omhandlet eldre, ikke omhandlet urinstiks, ikke omhandlet UVI eller omhandlet urinstiks tatt av inkontinensprodukter eller urinkateter. Vi leste i alt 15 i fulltekst, men her ble også elleve artikler ekskludert i og med at de omhandlet andre hjelpemidler, de omhandlet ikke urinstiks, eller de tok ikke for seg den eldre befolkningen. Vi gjennomgikk referanselistene til artiklene vi fant, og inkluderte ytterligere to artikler i studien. Flytdiagrammet i figur 2 illustrerer søke- og utvalgsprosessen.

I litteraturgjennomgangen inkluderte vi totalt seks artikler. Vi analyserte artiklene ved å sette dem inn i en litteraturmatrise (21-26) og vurdere dem etter PRISMA-kriteriene (27). Vi kategoriserte funnene etter land studiene ble utført i, type urinstiks som ble brukt, antall deltakere, studiedesign, hensikten med studiene og resultatene fra studiene. 


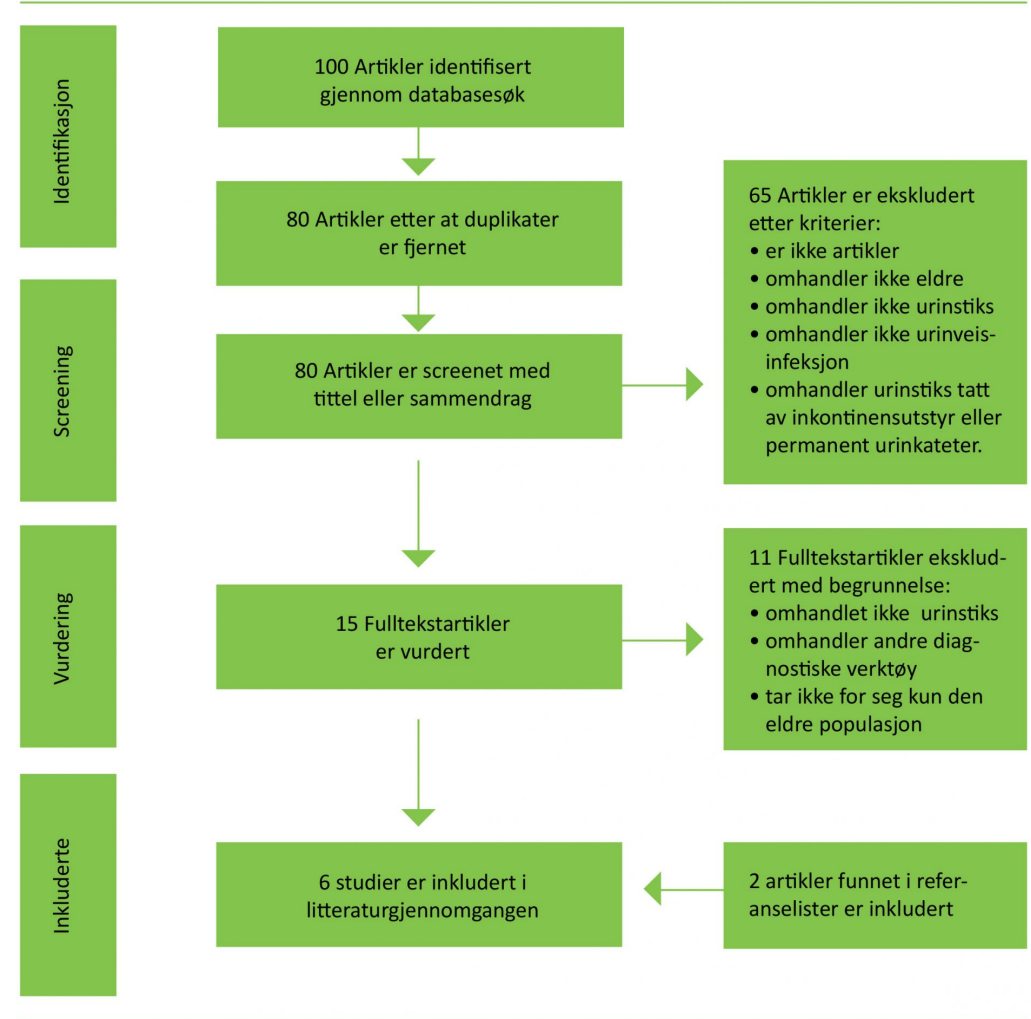

Kilde: http://www.prisma-statement.org/

\section{Resultater}


Det systematiske litteratursøket resulterte i gjennomgang av seks artikler som omhandlet hvor pålitelige urinstiks var i diagnostisering av urinveisinfeksjon hos eldre pasienter. De inkluderte studiene sammenlikner urinstiksprøvesvar og urinprøvedyrkingssvar hos eldre pasienter. Urinprøvedyrkingen brukes som gullstandard for å vurdere nøyaktigheten av urinstiks. Resultatene fra de seks inkluderte studiene er presentert i tabell 2 i form av en litteraturmatrise over de inkluderte studiene. Studiene ser på leukocytter og nitritt som indikatorer på bakteriuri og beregner sensitiviteten, spesifisiteten, den positive prediktive verdien (PPV) og den negative prediktive verdien (NPV) av urinstiks som hjelpemiddel. Diagnostisk sensitivitet og spesifisitet angir testens evne til å identifisere friske og syke i en gruppe, mens PPV og NPV angir henholdsvis sjansen for at pasienten er syk når testen er positiv, og sjansen for at pasienten ikke er syk når testen er negativ. Resultatene blir fremstilt i prosent, slik at en feilfri urinstiks ville vist en sensitivitet, spesifisitet, PPV og NPV på 100 prosent. Tabell 3 er en sammenstilling av resultatene for sensitivitet, spesifisitet, PPV og NPV i de inkluderte studiene (21-26). 
Tabell 2: Oversikt over de inkluderte studiene

\begin{tabular}{|c|c|c|c|c|c|c|}
\hline $\begin{array}{l}\text { Forfatter, } \\
\text { årstall }\end{array}$ & $\begin{array}{l}\text { Land/ } \\
\text { sted }\end{array}$ & Hensikt & $\begin{array}{l}\text { Studie- } \\
\text { design }\end{array}$ & Utvalg & Resultat & $\begin{array}{l}\text { Type } \\
\text { urinstiks }\end{array}$ \\
\hline $\begin{array}{l}\text { Sundvall \& } \\
\text { Gunnars- } \\
\text { son, } 2009\end{array}$ & $\begin{array}{l}\text { Sverige } \\
\text { Sykehjem }\end{array}$ & $\begin{array}{l}\text { Evaluere den } \\
\text { diagnostiske } \\
\text { nøyaktigheten } \\
\text { av urinstiks } \\
\text { blant eldre på } \\
\text { sykehjem utført } \\
\text { av ikke-lab-per- } \\
\text { sonell, og } \\
\text { sammenlikne } \\
\text { manuell lesing } \\
\text { av urinstiks og } \\
\text { analysator (Clin- } \\
\text { itek 50). }\end{array}$ & $\begin{array}{l}\text { Tver- } \\
\text { snittsstudie }\end{array}$ & $\begin{array}{l}651 \\
\text { deltakere }\end{array}$ & $\begin{array}{l}207 / 651 \text { pasienter viste } \\
\text { bakteriuri. Ingen forskjell } \\
\text { i manuell prøvetaking } \\
\text { med urinstiks og analysa- } \\
\text { tor. Noe mer pålitelig } \\
\text { med utslag på nitritt enn } \\
\text { leukocytter, men når } \\
\text { begge er til stede, } \varnothing \text { ker } \\
\text { diagnostikken. Men man } \\
\text { kan ikke utelukke at bak- } \\
\text { teriuri ikke er til stede. } \\
\text { Ved negativ urinstiks er } \\
\text { sannsynligheten høy for } \\
\text { at det ikke er bakteriuri } \\
\text { til stede. }\end{array}$ & Multistix 5 \\
\hline $\begin{array}{l}\text { Arinzon et } \\
\text { al., } 2009\end{array}$ & $\begin{array}{l}\text { Israel } \\
\text { Sykehjem }\end{array}$ & $\begin{array}{l}\emptyset \text { nsker å avg- } \\
\text { jøre validiteten } \\
\text { av urinstiks } \\
\text { sammenliknet } \\
\text { med standard } \\
\text { urinanalyse for } \\
\text { tidlig å oppdage } \\
\text { UVI hos langtid- } \\
\text { spasienter. }\end{array}$ & $\begin{array}{l}\text { Kasuskon- } \\
\text { trollstudie }\end{array}$ & $\begin{array}{l}192 \\
\text { deltakere }\end{array}$ & $\begin{array}{l}\text { Urinstiks som er positiv } \\
\text { på leukocytt og/eller } \\
\text { nitritt er ikke spesifikke } \\
\text { indikatorer for UVI og er } \\
\text { ikke passende å bruke } \\
\text { for å screene langtid- } \\
\text { spasienter for UVI på } \\
\text { grunn av høye falskt neg- } \\
\text { ative verdier på leukocytt } \\
\text { og nitritt. } \\
\text { Blod og protein hadde in- } \\
\text { gen betydning for å tolke } \\
\text { om stiksene viste positive } \\
\text { resultater. }\end{array}$ & $\begin{array}{l}\text { Multistix } \\
10\end{array}$ \\
\hline $\begin{array}{l}\text { Juthani-Me- } \\
\text { hta et } \\
\text { al., } 2007\end{array}$ & $\begin{array}{l}\text { USA } \\
\text { sykehjem }\end{array}$ & $\begin{array}{l}\text { Studien ser på } \\
\text { hvorvidt en } \\
\text { negativ urinstiks } \\
\text { kan utelukke } \\
\text { UVI. }\end{array}$ & $\begin{array}{l}\text { Tversnitts- } \\
\text { studie }\end{array}$ & $\begin{array}{l}101 \\
\text { deltakere }\end{array}$ & $\begin{array}{l}\text { Studien viser at en nega- } \\
\text { tiv urinstiks kan indikere } \\
\text { at man kan ekskludere } \\
\text { diagnosen UVI uten å } \\
\text { sende uricult. } \\
\text { Sensitivitet } 100 \text { prosent } \\
\text { Spesifisitet: } 20 \text { prosent }\end{array}$ & $\begin{array}{l}\text { Chemstrip } \\
\text { 10SG }\end{array}$ \\
\hline $\begin{array}{l}\text { Ouslander } \\
\text { et al., } 1995\end{array}$ & $\begin{array}{l}\text { USA } \\
\text { Sykehjem }\end{array}$ & $\begin{array}{l}\text { Undersøker } \\
\text { nøyaktigheten } \\
\text { av urinstiks } \\
\text { blant inkonti- } \\
\text { nente pasienter } \\
\text { på sykehjem } \\
\text { med asymp- } \\
\text { tomatisk bakte- } \\
\text { riuri. }\end{array}$ & $\begin{array}{l}\text { Tversnitts- } \\
\text { studie }\end{array}$ & $\begin{array}{l}214 \\
\text { deltakere } \\
\text { (684 } \\
\text { urin- } \\
\text { prøver) }\end{array}$ & $\begin{array}{l}\text { Bakteriuri var vanligere } \\
\text { hos kvinner: } \\
\text { Kvinner } 57 \text { prosent } \\
\text { Menn } 25 \text { prosent } \\
\text { Verken leukocytter eller } \\
\text { nitritt eller en kombinas- } \\
\text { jon av de to var adekvat } \\
\text { for sensitivitet eller spesi- } \\
\text { fisitet for klinisk bruk. }\end{array}$ & Multistix \\
\hline $\begin{array}{l}\text { Evans et al., } \\
1991\end{array}$ & $\begin{array}{l}\text { England } \\
\text { Sykehus }\end{array}$ & $\begin{array}{l}\text { Undersøker } \\
\text { nøyaktigheten } \\
\text { av urinstiks ved } \\
\text { å se på nitritt, } \\
\text { blod, protein, } \\
\text { og leukocytter } \\
\text { for tidlig å op- } \\
\text { pdage UVI hos } \\
\text { eldre. }\end{array}$ & $\begin{array}{l}\text { Tversnitts- } \\
\text { studie }\end{array}$ & $\begin{array}{l}100 \\
\text { deltakere }\end{array}$ & $\begin{array}{l}\text { Utslag på nitritt på en } \\
\text { urinstiks gir en hurtig } \\
\text { og reliabel indikator på } \\
\text { tilstedeværelsen av UVI } \\
\text { hos eldre. } \\
\text { Nitritt } 90 \text { prosent sen- } \\
\text { sitivitet og } 100 \text { prosent } \\
\text { spesifisitet. }\end{array}$ & Chemstrip \\
\hline $\begin{array}{l}\text { Ducharme } \\
\text { et al., } 2007\end{array}$ & $\begin{array}{l}\text { Canada } \\
\text { Sykehus } \\
\text { - akutt- } \\
\text { avdeling }\end{array}$ & $\begin{array}{l}\text { Unders } \varnothing \text { ker } \\
\text { resultater av } \\
\text { urinprøver } \\
\text { sendt til dyrk- } \\
\text { ing og urinstiks } \\
\text { i to grupper } \\
\text { for å identi- } \\
\text { fisere hvorvidt } \\
\text { verkt } \varnothing y e n e \\
\text { kan bidra til å } \\
\text { diagnostisere } \\
\text { UVI hos eldre i } \\
\text { akuttavdeling. }\end{array}$ & $\begin{array}{l}\text { Tversnitts- } \\
\text { studie }\end{array}$ & $\begin{array}{l}200 \\
\text { deltak- } \\
\text { ere }\end{array}$ & $\begin{array}{l}\text { Bruk av urinstiks hos } \\
\text { eldre for å identifisere } \\
\text { bakteriuri er upålitelig. } \\
\text { Videre viser det seg at } \\
\text { positive urinprøver sendt } \\
\text { til dyrking bare er noe } \\
\text { høyere hos pasienter } \\
\text { med vage symptomer på } \\
\text { UVI som pasienter uten } \\
\text { symptomer. Dette kan } \\
\text { tyde på at flere har ASB } \\
\text { og ikke UVI. }\end{array}$ & Multistix 8 \\
\hline
\end{tabular}




\begin{tabular}{|c|c|c|c|c|c|c|c|c|}
\hline & & Sensitivitet & & & Spesifisitet & & PPV & NPV \\
\hline Studie & LE & $\mathbf{N i}$ & $\begin{array}{l}\text { LE el. } \\
\mathrm{Ni}\end{array}$ & LE & $\mathrm{Ni}$ & $\begin{array}{l}\text { Le el. } \\
\mathrm{Ni}\end{array}$ & $\begin{array}{l}\text { Le el. } \\
\mathrm{Ni}\end{array}$ & $\begin{array}{l}\text { Le el. } \\
\mathrm{Ni}\end{array}$ \\
\hline $\begin{array}{l}\text { Sundvall \& Gun- } \\
\text { narsson, } 2009\end{array}$ & 69 & 57 & 82 & 64 & 92 & 61 & 51 & 88 \\
\hline $\begin{array}{l}\text { Arinzon et al., } \\
2009\end{array}$ & 86 & 75 & 72 & 48 & 48 & 67 & 85 & 49 \\
\hline $\begin{array}{l}\text { Juthani-Mehta et } \\
\text { al., } 2007\end{array}$ & 98 & & 100 & 26 & & 20 & 45 & 100 \\
\hline $\begin{array}{l}\text { Ouslander et al., } \\
1995\end{array}$ & 82 & 54 & 88 & 59 & 93 & 57 & 93 & 85 \\
\hline $\begin{array}{l}\text { Evans et al., } \\
1991\end{array}$ & 72 & 83 & & 81 & 100 & & & \\
\hline $\begin{array}{l}\text { Ducharme et al., } \\
2007\end{array}$ & & & 74 & & & 70 & 31 & 93 \\
\hline
\end{tabular}

Tallene er oppgitt i prosent.

Forkortelser: $\mathrm{LE}=$ leukocytter, $\mathrm{Ni}=$ nitritt, $\mathrm{PPV}=$ Positiv prediktiv verdi, $\mathrm{NPV}=$ negativ prediktiv verdi.

\section{Sensitivitet og spesifisitet}

Sensitivitet beskriver urinstiksens evne til å oppdage om pasienten har bakteriuri. I de ulike studiene viste sensitiviteten seg å være veldig sprikende. JuthaniMehta et al. (23) viste at en urinstiks som hadde utslag på nitritt eller leukocytter eller begge deler, hadde en sensitivitet på 100 prosent. Derimot viste Arinzon et al. (22) en sensitivitet på 72 prosent. Det er ikke alle studiene som sier noe om sensitiviteten for nitritt og leukocytter alene, men i de studiene hvor dette gjøres, spriker resultatene fra 69-98 prosent på leukocytter og fra 54-83 prosent på nitritt.

I motsetning til sensitivitet brukes spesifisitet for å beskrive urinstiksens evne til å oppdage om pasienten ikke har bakteriuri. Spesifisiteten varierer i de ulike studiene. Juthani-Mehta et al. (23) så på tilfeller der urinstiks er positiv på leukocytter og nitritt, eller en av delene. Da viser spesifisiteten 20 prosent. Den kanadiske studien til Ducharme et al. (26) viser derimot en spesifisitet på 70 prosent. Når leukocytter alene er undersøkt, viser det en spesifisitet fra 26-81 prosent. Nitritt, derimot, har en spesifisitet fra 48-100 prosent.

\section{Positiv prediktiv verdi og negativ prediktiv verdi}


Positiv prediktiv verdi (PPV) og negativ prediktiv verdi (NPV) forteller oss om sannsynligheten for at urinstiks gir et riktig resultat. Alle studiene, med unntak av Evans et al. (25), sier noe om PPV og NPV når både leukocytter og nitritt er til stede, eller når leukocytter eller nitritt alene gir utslag på urinstiks. PPV viser en prosent fra 31-93 i de ulike studiene, mens NPV varierer fra 49-100 prosent.

\section{Andre relevante funn}

Alle de seks inkluderte studiene unntatt Evans et al. (25) så på både leukocytter og nitritt som reagenser. Det vil si enten at nitritt eller leukocytter var til stede, eller at urinstiks ga utslag på begge variablene. Flere av studiene så også på hvorvidt det var utslag på proteiner og blod. Når det gjelder proteiner og blod, viste ingen av studiene at disse reagensene har noen signifikans for å konstatere bakteriuri hvis dette gir utslag på urinstiks. Utslag på protein og blod er dermed ikke pålitelige indikatorer på UVI. Videre sammenlikner Sundvall et al. (21) også manuell lesing av urinstiks med automatisk analysator av type Clinitek 50. Studien viser at metoden på prøvetakingen ikke utgjør noen forskjell, altså er det like gode eller dårlige resultater ved manuell som automatisk avlesning.

\section{Lite forskning på området}


UVI er en av de hyppigste bakterielle infeksjonene i den eldre populasjonen. Likevel er UVI ofte overdiagnostisert og overbehandlet blant eldre på bakgrunn av uspesifikke kliniske tegn og symptomer og høy forekomst av ASB hos eldre (5) som ikke skal behandles ifølge kliniske retningslinjer $(7,9,28)$. Til tross for at en urinstiks ikke kan skille mellom en ASB og en UVI, er det vanlig å bruke urinstiks for å diagnostisere UVI hos eldre pasienter. I de fleste tilfeller er urinstiks hyppig brukt i klinikken, og oppstart av antibiotika kan skje på bakgrunn av en positiv urinstiks frem til et dyrkingssvar av urinprøve eventuelt foreligger (26). Ettersom urinstiks tilsynelatende er mye brukt i klinikken og resultatet av urinstiks har en avgjørende rolle i diagnostiseringen av UVI hos eldre, er det interessant å se på hvor pålitelig urinstiks er. Hensikten med denne litteraturstudien var å vurdere påliteligheten av urinstiks for diagnostisering av UVI hos eldre pasienter i sykehjem og hjemmetjenester. Til tross for omfattende og systematisk litteratursøk fant vi kun seks forskningsartikler som omhandler det aktuelle temaet. Dette lave antallet kan man stille seg undrende til når bruken av urinstiks er så utbredt.

\section{三 ««Det er et kjent problem med overbehandling av urinveisinfeksjon.»"»}

Det er forsket mye på urinstiks innenfor andre populasjoner som barn, yrkesaktive voksne og fortrinnsvis kvinner. Disse studiene gir ulike resultater avhengig av aldersgruppe og pasientkriterier (21).

Gravide er en annen gruppe som det er forsket mye på, og i denne populasjonen er urinstiks anbefalt å bruke for å oppdage bakteriuri (18). Kombinasjonen av eldre og bruken av urinstiks finnes det derimot lite forskningslitteratur på, noe som Bevridge et al. (5) understøtter. Denne litteraturstudien er derfor et viktig bidrag til å gi kunnskap om bruk av urinstiks hos en populasjon som er mye plaget med UVI, men som har høy forekomst av ASB. 


\section{Bruke urinstiks i klinikken}

Om allmenntilstanden eller atferden til en eldre pasient endrer seg i dag, er gjerne en UVI det første man mistenker. En urinstiks er et enkelt, billig og lite inngripende hjelpemiddel å benytte seg av for å bekrefte eller avkrefte om en pasient har UVI, og blir derfor ofte brukt. Hvis en urinstiks viser seg å være positiv ved at den gir utslag på nitritt og leukocytt, er praksisen gjerne at lege blir kontaktet (17), ofte over telefon, og antibiotika blir rekvirert (29).

At bruk av urinstiks har en så utbredt praksis i Norge, er ikke så underlig. Det står nemlig i de norske retningslinjene for antibiotikabruk i primærhelsetjenesten (7) at leukocytter- og nitrittesten på en urinstiks kan bidra til å avklare om det foreligger en infeksjon. Det står videre at mikroskopi av urinen ikke gir noen tilleggsopplysninger for bruken av urinstiks, at leukocytter har en god utslagsverdi (sensitivitet og spesifisitet er cirka 85 prosent), og at en positiv nitrittest er ensbetydende med gramnegative staver når urinen har stått fire timer $\mathrm{i}$ urinblæren (spesifisitet 96 prosent) (7). Med andre ord har norske retningslinjer stor tiltro til urinstiks som diagnostisk hjelpemiddel.

\section{Sykepleieren har en sentral rolle}

En studie viser at leger ofte velger å ordinere antibiotika på bakgrunn av en positiv urinstiks frem til det foreligger et dyrkingssvar (30). En slik fremgangsmåte har imidlertid vist seg å ha en feildiagnostisering på 20-40 prosent. En slik feildiagnostisering er svært uheldig da behandling med antibiotika hos eldre kan føre til resistensutvikling og uønskete bivirkninger. I verste fall kan det også føre til at man ikke oppdager den faktiske underliggende årsaken til pasientens symptomer $(2,10)$. 
Videre har sykepleieren vist seg å ha en sentral rolle i diagnostiseringen av UVI hos eldre. Det er sykepleieren som daglig observerer pasientenes tilstand og symptomer, som ordinerer urinkulturer, tar urinstiks og har innvirkning på oppstart av antibiotika (17). Nettopp derfor er det viktig at sykepleiere innehar kunnskap om UVI hos eldre, slik at de kan gjøre de riktige vurderingene. En del av denne vurderingen er å kunne tolke og kjenne begrensningene til en urinstiks.

\section{Er urinstiks et pålitelig hjelpemiddel?}

Studiene av nyere dato som er inkludert i denne litteraturstudien (21-23, 26), understreker at urinstiks ikke er et godt nok hjelpemiddel til å fastslå bakteriuri hos eldre pasienter. De viser til resultater hvor det er mange falske positiver og der sensitiviteten og spesifisiteten er lav, det vil si at urinstiks ikke er pålitelig til å skille friske og syke når det gjelder UVI. Duchrame et al. (26) fant at 61 prosent av pasienter med positiv urinstiks ikke hadde bakteriuri etter dyrkingssvar. Sundvall et al. (21) viste at med en positiv urinstiks er sannsynligheten for bakteriuri bare 51-73 prosent.

Deville et al. (31) har gjort en metaanalyse der de konkluderer med at urinstiks alene kan være nyttig i alle populasjoner for å ekskludere tilstedeværelsen av infeksjon når det ikke er utslag verken på både nitritt eller leukocytter. Selv om denne metaanalysen har basert seg på et fåtalls antall artikler som omhandler eldre, samsvarer funnene godt med funnene i de inkluderte artiklene i litteraturstudien vår. De inkluderte studiene har en NPV fra 88-100 prosent, med unntak av studien til Arinzon et al. (22), som har en NPV på 49 prosent. Dette tyder altså på at urinstiks ikke er et særlig pålitelig hjelpemiddel for å fastslå UVI, men at det er mer pålitelig til å avkrefte UVI hos eldre pasienter. 


\section{Har ikke bedre hjelpemidler}

Selv om urinstiks ikke er særlig pålitelig i

diagnostiseringen av UVI hos eldre, har vi foreløpig

ikke noe hjelpemiddel som er bedre. Det er gjort en

rekke studier for å vurdere hvor pålitelige andre

hjelpemidler er for å diagnostisere UVI. McGeer-

kriteriene og Loeb-kriteriene er begge korte sjekklister

for å diagnostisere UVI ved hjelp av kliniske tegn som temperaturstigning, brennende smerte ved vannlating, hyppig vannlating, suprapubisk smerte, endring i urinens karakter, bankeømhet over nyrene, uttalt blodig urin, urininkontinens og forverring av mental status (8, 32). Juthani-Mehta et al. utførte en studie i 2007 der de evaluerte hvorvidt sykehjemspasienter med mistanke om UVI møtte Loeb- eller McGeerkriteriene, og om de var i tråd med laboratoriesvarene (33). Her viste McGeer-kriteriene seg å ha en sensitivitet på 30 prosent, spesifisitet på 82 prosent, PPV på 57 prosent og NPV på 61 prosent. Loebkriteriene hadde nesten likt resultat - det vil si liten pålitelighet til å diagnostisere UVI.

\section{三 ««Sykepleieren har en sentral rolle i diagnostiseringen av urinveisinfeksjon hos eldre.»"»}

Videre gjorde Juthani-Mehta et al. (34) en studie der de identifiserer kliniske tegn i sammenheng med bakteriuri og pyuri (hvite blodceller i urinen) hos sykehjemspasienter ved mistanke om UVI. De viste at dysuri (smertefull vannlating), endring i karakter av urinen og endring i mental status har sammenheng med bakteriuri kombinert med pyuri, men denne studien ga ingen bedre resultater enn diagnostikk med urinstiks. 
Sundvall et al. (35) undersøkte om høyere

konsentrasjon av Interleukin-6 i urinen kunne indikere

hvorvidt pasienten hadde UVI med uspesifikke

symptomer. Interleukin-6 er en mediator for betennelse som spiller en viktig rolle i immunsystemets

regulering. Stoffet kan undersøkes ved en urinanalyse.

Denne studien viste at verken økt konsentrasjon av

Interleukin-6 i urinen eller bruk av urinstiks egner seg som indikator på uspesifikke symptomer og bakterier i urinen hos den eldre befolkningen.

\section{Implikasjoner for praksis}

Som nevnt er urinstiks et hurtig, lite inngripende og billig hjelpemiddel, men tilsynelatende ikke så pålitelig. Ettersom det ser ut til at vi ikke har noe annet hjelpemiddel som er bedre, er det kanskje hensiktsmessig å fortsette å bruke urinstiks, forutsatt at metoden utføres korrekt og tolkes riktig. Sykepleieren må også kjenne urinstiksens begrensninger.

I figur $3(4,7-10,13-16,36)$ forsøker vi å gi en oversikt over urinstiksens begrensninger når det gjelder hvilke faktorer som kan gi falskt positivt og falskt negativt svar. Det vil være en styrke for sykepleieren å besitte denne kunnskapen for å vurdere hvor pålitelig resultatet av en urinstiks er. Videre kan figur 3 også brukes som en klinisk veiledning for når urinstiks skal tas, og for hvordan man skal handle videre etter at urinprøven er tatt.

Figur 3: Veiledning for sykepleiere for bruk av urinstiks hos eldre ved mistanke om UVI

Vanlige symptomer på UVI

- Smerter og svie ved vannlating

- Hyppig vannlatning

- Nyoppstått $\varnothing k t$ vannlatingstrang og ev. lekkasje

- Suprapubiske smerter

- Temperatur over 37,9 grader eller 1,5 grader over normalen oftest til stede ved $\emptyset$ vre UVI

Ta urinstiks og vurder referanseområdene på leukocytt og nitritt som kan indikere UVI.
Ikke-spesifikke symptomer på UVI

- Vaginal irritasjon

- Inkontinens

- Endring i urinens karakter

- Endring i mental status, uro,

aggresjon

- Falltendens

- ADL-svikt
Avvent behandling og observer symptomer. Oppmuntre til økt væskeinntak. 
Positiv urinstiks på leukocytt og nitritt. Vær oppmerksom på at en urinstksx har høy forekomst av falske positiver. Ta urinstiksens begrensning $\mathrm{i}$ betraktning.
Negativ urinstiks på leukocytt og nitritt. Trolig ingen UVI, men ta urinstiksens begrensning i betraktning.

Utvikling av van-
lige symptomer
på UVI og/eller
forverring av
mental status.

Forbedring av symptomer.

Vurder andre diagnoser/ tilstander.

Lege kontaktes antibiotikabehandling vurderes.

Urinprøve til dyrking $b ø r$ tas og sendes $f \varnothing r$ oppstart av antibiotika.

\section{Slik tar man en urinstiks}

1. Utfør urinprøvetaking ved en ren fangst (clean catch) midtstrøms urinprøve, helst av morgenurin i en ren beholder.

2.Utfør testen helst i fersk urin. Urin som har stått i mer enn to timer, gir ofte unøyaktige resultater.

3. Dypp teststrimmelen i urinen, men ikke lenger enn ett sekund (ellers kan reagensen gå i oppløsning). Alle reagensområdene må være dekket av urin.

4. Dra urinstiksen opp langs kanten av beholderen med urin i en horisontal vinkel. Dette vil fjerne overflødig urin og hindre at kjemikalier fra de andre reagensmiddelområdene blir blandet.

5. Etter angitt tid på pakningen til urinstiks er resultatene klare (ofte 60-120 sekunder).

6. Sammenlikn reaksjonen på fargen i testområdet på urinstiks mot fargeskalaen på etiketten på pakningen.

\section{Urinstiksens begrecyttest
Forhold som kan gi falske
positiver:
- Forurensning. Kan komme fra
vagina eller forhudssekret.
- Urinstiks som har gått ut på
dato, blitt forurenset eller
oppbevart feil.
- Enkelte typer antibiotika
farger urinen og maskerer un-
ormale funn. Eks. nitrofuran-
toin (Furadantin), imipenem,
meropenem, amoxicillin}

Forhold som kan gi falske negativer:

- $\emptyset$ kt spesifikk vekt i urinen.

- Forh øyete glukoseverdier i urinen.

- Ketoner eller proteiner i urinen.

- Bruk av oksyderende legemidler som cefalexin (Keflex), nitrofurantoin (Furadantin), gentamisin eller tetracyclin.

- Bruk av C- vitamin.

- Urinprøven er ikke blandet godt eller tatt ved en lav temperatur (under romtemperatur).

\section{Nitrittest}

Forhold som kan gi falske positiver:

- Urinstiks som har gått ut på dato, blitt forurenset eller oppbevart feil. Ntritttesten er veldig sensitiv for luft.

- Legemidler som farger urinen rød, for eksempel fenazopyridin.

- Bakteriell forurensning fra prøvetaking.

- Bakterier kan formere seg og omdanne nitrat til nitritt i prøver som er mer enn fire timer gamle.

Forhold som kan gi falske negativer:

- Det er i hovedsak gram-negative bakterier som blir omgjort fra nitrat til nitritt. Flere gram positive bakterier, som for eksempel enterokokker, lager ikke nitrat, og vil da ikke gi utslag på nitritt.

- Urinen må ha stått i fire timer i urinblæren for at nitrat blir omgjort til nitritt.

- Bruk av C- vitamin.

- PH lavere enn seks.

- $\varnothing$ kt spesifikk vekt i urinen (ses på en reagens på urinstiksen).

- Pasienter som har lite nitrat i kostholdet.

- Forhøyet verdi av urobilinogen i urinen

\section{Styrker og svakheter}


Denne litteraturstudiens største svakhet er at den er basert på kun seks artikler fordi det er gjort lite forskning på eldre pasienter og påliteligheten av urinstiks. Det er derfor vanskelig å trekke bastante konklusjoner. Alle de inkluderte studiene er publisert i store og anerkjente tidsskrifter med fagfellevurdering som et tegn på forskningens kvalitet. Vi vil likevel bemerke at den eldste studien som er inkludert, har en svak beskrivelse av sin metodiske fremgangsmåte (25).

En styrke ved studien vår er at de inkluderte studiene kun bruker to ulike typer urinstiks: merkene Multistix fra Bayer eller Chemstrip fra Roche. Videre er studiene ensartete ved at de har brukt dyrkingssvar av urinen som gullstandarden, og alle har brukt samme grenseverdi på 10^5 bakterier pr./ml som signifikant bakteriuri. Dette styrker sammenlikningene gjort i denne litteraturstudien. Hvorvidt funnene fra de ulike studiene kan overføres til norske forhold, er høyst tenkelig. De er utført i seks ulike land. Den største studien er utført i Sverige, som er et land vi kan sammenlikne oss med når det gjelder eldreomsorgsstruktur og den eldre befolkningen. I alle de undersøkte studiene ble urinprøvene dyrket. Der så man at bakteriefunnene var like, og at de samsvarte med litteraturen som finnes på området.

\section{Konklusjon}


Urinstiks ser ikke ut til å være et hensiktsmessig hjelpemiddel i diagnostiseringen av UVI hos eldre fordi den er lite pålitelig og ikke kan skille mellom en UVI og en ASB. Tross dette har vi tilsynelatende ikke noe annet hjelpemiddel som er bedre. Sykepleiere har vist seg å ha en viktig rolle i urinprøvetaking, bruk av urinstiks og oppstart av antibiotikabehandling mot UVI hos eldre pasienter. Derfor er det viktig at sykepleiere kjenner til begrensningene til en urinstiks og indikasjoner for bruk. De må også kjenne til hvordan urinstiksen skal tolkes. Urinveisinfeksjon blant eldre pasienter på sykehjem og i hjemmetjenester er svært utbredt, men på grunn av at det er vanskelig å stille diagnosen i denne befolkningsgruppen, er det stor overbehandling med antibiotika. Overbehandling er lite ønskelig fordi det fører til resistensutvikling, uønskete bivirkninger og økte kostnader. Videre forskning på differensialdiagnostikken mellom UVI og ASB vil være avgjørende i fremtiden.

\section{Referanser}

1. Omli R, Skotnes LH, Mykletun A, Bakke AM, Kuhry E. Residual urine as a risk factor for lower urinary tract infection: A 1-year follow-up study in nursing homes. J Am Geriatr Soc. 2008;56(5):871-74.

2. Wyller TB. Geriatri : en medisinsk lærebok. Oslo:

Gyldendal Akademisk; 2011.

3. Hunskår S, Brekke M, Hjortdahl P, Holtedahl K, Sandvik H, Smith-Sivertsen T. Allmennmedisin. Oslo: Gyldendal Norsk Forlag; 2013.

4. Willacy H, Henderson R, Bonsall A. Urine dipstick analysis. Patient 2014-2015. Tilgjengelig fra: http://www.patient.co.uk/doctor/urine-dipstick-analysis (Nedlastet 14.04.2015).

5. Bevridge LA, Davey PG, Phillips G, McMurdo ME. Optimal management of urinary tract infections in older people. Clinical Interventions in Aging. 2011;6:173-80. 
6. Sundvall PD, Ulleryd P, Gunnarsson RK. Urine culture doubtful in determining etiology of diffuse symptoms among elderly individuals: a cross-sectional study of 32 nursing homes. BMC Fam Pract.

2011;12:36.

7. Helsedirektoratet. Antibiotikabruk i

primærhelsetjenesten. Nasjonal faglig retningslinje for antibiotikabruk i primærhelsetjenesten. Tilgjengelig fra: https://helsedirektoratet.no/retningslinjer/nasjonalfaglig-retningslinje-for-antibiotikabruk-iprimerhelsetjenesten (Nedlastet 08.08.2016).

8. Rowe TA, Juthani-Mehta M. Diagnosis and management of urinary tract infection in older adults. Infect Dis Clin North Am. 2014;28(1):75-89.

9. Fekete T, Hooton TM, Calderwood SB, Bloom A. Approach to the adult with asymptomatic bacteriuria 2015. Tilgjengelig fra:

http://www.uptodate.com/contents/approach-to-theadult-with-asymptomatic-bacteriuria (Nedlastet 01.05.2015).

10. Mody L, Juthani-Mehta M. Urinary tract infections in older women: a clinical review. Jama.

2014;311(8):844-54.

11. Knudsen J, Frimodt-Møller N. Ældre får flere bivirkninger og mere resistensudvikling af antibiotika. Ugeskr Læger 2013;175:2854-7.

12. Tobiassen T, Berild D, Hjortdahl P. Bruk av systemiske antibiotika ved et norsk sykehjem. Tidsskr Nor Laegeforen. 2002;122(24):2376-8. Tilgjengelig fra: http://tidsskriftet.no/article/606500/ (Nedlastet 08.08.2016).

13. Roche. Compendium of urinalysis: Urine test strips and microscopy 2010. Tilgjengelig fra:

http://www.cobas.com/content/dam/cobas_com/pdf/product/urinalysiscompendium.pdf (Nedlastet 20.04.2015). 
14. Simerville JA, Maxted WC, Pahira JJ. Urinalysis: a comprehensive review. Am Fam Physician.

2005;71(6):1153-62.

15. Wilson LA. Urinanalysis. Nurs Stand.

2005;19(35):51-4.

16. Hegdal SM, Brønstad G, Kümmel A. Informasjon fra Avdeling for laboratoriemedisin (ALM) 2013.

Tilgjengelig fra: https://ekstranett.helse-

midt.no/Samhandling/hnt/lab-nytt/Labnytt/Lab-

nytt\%202005-2013.pdf (Nedlastet 02.09.2016).

17. Walker S, McGeer A, Simor AE, Armstrong-Evans

M, Loeb M. Why are antibiotics prescribed for

asymptomatic bacteriuria in institutionalized elderly

people? A qualitative study of physicians' and nurses'

perceptions. Canadian Medical Association Journal.

2000;163:273-7. Tilgjengelig fra:

http://www.ncbi.nlm.nih.gov/pubmed/10951723

(Nedlastet 08.08.2016).

18. Krogsboll LT, Jorgensen KJ, Gotzsche PC.

Screening with urinary dipsticks for reducing morbidity and mortality. Cochrane Database Syst Rev. 2015;1:CD010007.

19. Loeb M, Brazil K, Lohfeld L, McGeer A, Simor A, Stevenson K et al. Effect of a multifaceted intervention on number of antimicrobial prescriptions for suspected urinary tract infections in residents of nursing homes: cluster randomised controlled trial. BMJ. 2005;331(7518):669. Tilgjengelig fra: http://www.bmj.com/content/331/7518/669 (Nedlastet 08.08.2016).

20. Lammers RL, Gibson S, Kovacs D, Sears W, Strachan G. Comparison of test characteristics of urine dipstick and urinalysis at various test cut- off points. Ann Emerg Med. 2001;38:505-12. Tilgjengelig fra: http://www.ncbi.nlm.nih.gov/pubmed/11679861 (Nedlastet 08.08.2016). 
21. Sundvall PD, Gunnarsson RK. Evaluation of dipstick analysis among elderly residents to detect bacteriuria: a cross-sectional study in 32 nursing homes. BMC geriatr. 2009;9:32.

22. Arinzon Z, Peisakh A, Shuval I, Shabat S, Berner YN. Detection of urinary tract infection (UTI) in longterm care setting: Is the multireagent strip an adequate diagnostic tool? Arch Gerontol Geriatr. 2009;48(2):227-31.

23. Juthani-Mehta M, Tinetti M, Perrelli E, Towle V, Quagliarello V. Role of dipstick testing in the evaluation of urinary tract infection in nursing home residents. Infect Control Hosp Epidemiol. 2007;28(7):889-91.

24. Ouslander JG, Schapira M, Fingold S, Schnelle J. Accuracy of rapid urine screening tests among incontinent nursing home residents with asymptomatic bacteriuria. J Am Geriatr Soc. 1995;43(7):772-5.

25. Evans PJ, Leaker BR, McNabb WR, Lewis RR. Accuracy of reagent strip testing for urinary tract infection in the elderly. Journal of the Royal Society of Medicine. 1991;84(10):598-9.

26. Ducharme J, Neilson S, Ginn JL. Can urine cultures and reagent test strips be used to diagnose urinary tract infection in elderly emergency department patients without focal urinary symptoms? CJEM, Can. 2007;9(2):87-92.

27. Prisma. Preferred Reporting Items for Systematic Reviews and Meta-Analyses. Tilgjengelig fra: http://www.prisma-statement.org/ (Nedlastet 08.08.2016). 
28. High K, Schmader KE, Sokol HN. Evaluation of infection in the older adult 2014. Tilgjengelig fra: http://www.uptodate.com/contents/evaluation-ofinfection-in-the-older-adult?sourcesearch_result\&amp;searchinfection+elderly\&amp;selectedTitle=1\%7E13\#H1498008 (Nedlastet 08.08.2016).

29. Pettersson E, Vernby A, Molstad S, Lundborg CS. Infections and antibiotic prescribing in Swedish nursing homes: a cross-sectional study. Scand J Infect Dis. 2008;40(5):393-8.

30. Ackermann RJ, Monroe PW. Bacteremic urinary tract infection in older people. J Am Geriatr Soc. 1996;44(8):927-33. Tilgjengelig fra:

http://www.ncbi.nlm.nih.gov/pubmed/8708302 (Nedlastet 08.08.2016).

31. Deville WL, Yzermans JC, van Duijn NP, Bezemer $\mathrm{PD}$, van der Windt DA, Bouter LM. The urine dipstick test useful to rule out infections. A meta-analysis of the accuracy. BMC Urol. 2004;4(4).

32. Liu LM. UTIs in nursing home residents. Advance healthcare network 2015. Tilgjengelig fra: http://nursepractitioners-and-physicianassistants.advanceweb.com/Archives/ArticleArchives/UTIs-in-Nursing-Home-Residents.aspx (Nedlastet 26.04.2015).

33. Juthani-Mehta M, Tinetti M, Perrelli E, Towle V, Quagliarello V. Diagnostic accuracy of criteria for urinary tract infection in a cohort of nursing home residents. J Am Geriatr Soc. 2007;55(7):1072-77.

34. Juthani-Mehta M, Quagliarello V, Perrelli E, Towle V, Van Ness PH, Tinetti M. Clinical features to identify urinary tract infection in nursing home residents: a cohort study. J Am Geriatr Soc. 2009;57(6):963-70. 
35. Sundvall PD, Elm M, Ulleryd P, Molstad S, Rodhe $\mathrm{N}$, Jonsson $\mathrm{L}$ et al. Interleukin- 6 concentrations in the urine and dipstick analyses were related to bacteriuria but not symptoms in the elderly: a cross sectional study of 421 nursing home residents. BMC Geriatr. 2014;14:88.

36. Midthun S, Paur R, Bruce AW, Midthun P. Urinary tract infections in the elderly: A survey of physicians and nurses. Geriatr Nurs. 2005;26:245-51. 